\title{
Analiza zmiennych u pacjentów kardiologicznych
}

\section{Analysis of variables in cardiologic patients}

\author{
KAMILA BOROWSKA-SZCZEPUCHOWSKA ${ }^{1}$, MARIA POSŁUSZNA \\ - OWCARZ2 ${ }^{2}$ ANNA ANTCZAK ${ }^{3}$ \\ ${ }^{1}$ Specjalistyczny Szpital Wojewódzki w Ciechanowie \\ 2 Kujawska Szkoła Wyższa we Włocławku, Wydział Nauk o Zdrowiu \\ 3 Zakład Pielęgniarstwa Neurologicznego i Neurochirurgicznego, Collegium Medicum \\ w Bydgoszczy, Uniwersytet Mikołaja Kopernika w Toruniu, Państwowa Wyższa Szkoła \\ Zawodowa we Włocławku, Instytut Nauk o Zdrowiu
}

DOI: http://dx.doi.org/10.21784/IwP.2017.009

ISSN: 2451-1846

\section{Streszczenie:}

Wstęp. Według danych najczęstszymi przyczynami zgonów w Polsce są choroby układy krążenia. Rozwój technologii wpływa znacząco na zachorowalność kardiologiczną. Jednak jednoznacznie znaczny wpływ na umieralność wchorobach układu krążenia mają schorzenia związane z rozwojem miażdżycy tętnic należy do nich głównie choroba niedokrwienna serca, która jest przyczyną wielu przedwczesnych zgonów, które wystąpiły przed 65 rokiem życia. Wśród czynników ryzyka choroby niedokrwiennej serca znajduje się czynnik związany ze stylem życia (dieta wysokokaloryczna obfitująca w tłuszcze nasycone i cholesterol, palenie tytoniu, nadmierne spożycie alkoholu, mała aktywność fizyczna). 
Cel. Celem badań była ocena prowadzenia zdrowego stylu życia oraz kontroli stanu zdrowia przed i po zachorowaniu u pacjentów Oddziału Kardiologii i Pododdziału Intensywnej Opieki Kardiologicznej.

Materiał i metody. Badania przeprowadzono w Specjalistycznym Szpitalu Wojewódzkim w Ciechanowie. Grupę badaną stanowiło 70 pacjentów przebywających w Oddziale Kardiologii i Pododdziale Intensywnej Opieki Kardiologicznej. Badania przeprowadzono metodą sondażu diagnostycznego. Jako narzędzie badawcze wykorzystano kwestionariusz ankiety własnej konstrukcji.

Wyniki. Przeprowadzone badania pokazują, że przed zachorowaniem ok. 57\% badanych prowadziło zdrowy styl życia. Obecnie odsetek osób przyznających się do prawidłowych zachowań wzrósł aż do 87\%. Jednocześnie wyraźnie spadła liczba osób, które po zachorowaniu prowadza niezdrowy styl życia. Przed zachorowaniem co trzeci badany kontrolował swój stan zdrowia. Obecnie robią to prawie wszyscy pacjenci - 93\%. Wyraźnie spadał liczba osób, które obecnie, w porównaniu do czasu sprzed wystąpienia choroby nie kontrolowały swojego zdrowia. Obecnie jedynie 7\% pacjentów tego nie robi.

Wnioski. Prowadzenie zdrowego stylu życia oraz kontrola stanu zdrowia uległy poprawie po wystąpieniu choroby. Zebrany materiał badawczy stanowi podstawę do potwierdzenia hipotezy, że pacjenci w znacznej większości po wystąpieniu choroby zmieniają styl życia na bardziej prozdrowotny.

Słowa kluczowe: zdrowy styl życia, zachorowalność, choroby kardiologiczne

\begin{abstract}
:
Introduction. According to data, the most common causes of death in Poland are cardiovascular diseases. Technology development has a significant impact on cardiovascular morbidity. It is clear however, that mortality in cardiovascular diseases largely results from diseases related to atherosclerosis mainly due to ischemic heart disease, which is the cause of many premature deaths that occurred before the age of 65 . The risk factors for ischemic heart disease include: the risk factor associated with lifestyle
\end{abstract}


(high-calorie diet rich in saturated fats and cholesterol, smoking, excessive use of alcohol, low physical activity).

Aim. The purpose of the study was to evaluate healthy lifestyle and health status before and after treatment in patients of Cardiology and Intensive Care Unit.

Material and methods. The study was conducted in the Specialized Provincial Hospital in Ciechanów. The study group consisted of 70 patients staying in the Cardiology Ward and Intensive Care Unit. The study was conducted with the use of the diagnostic survey method. As a research tool, our own survey questionnaire was used.

Results. The study has shown that before the illness, approximately $57 \%$ of the patients led healthy lifestyle. Currently, the percentage of people admitting to right behavior has risen to $87 \%$. At the same time, the number of people who suffer from unhealthy lifestyles has dropped significantly. Prior to the disease, every third of the respondents controlled their health. Currently, almost all patients are doing this - 93\%. The number of patients who currently do not control their health compared to the period before the onset of illness was clearly down. Currently, only 7\% of patients do not do that.

\section{Conclusions.}

Keeping a healthy lifestyle and health check improved after the onset of the disease. The collected research material is the basis for confirming the hypothesis that patients in the majority after the onset of the disease change their lifestyle to a more healthy one.

Keywords: healthy lifestyle, morbidity, cardiac diseases

\section{Wstęp}

Według danych najczęstszymi przyczynami zgonów w Polsce są choroby układy krążenia. Rozwój technologii wpływa znacząco na zachorowalność kardiologiczną. Jednak jednoznacznie znaczny wpływ na umieralność w chorobach układu krążenia mają schorzenia związane $\mathrm{z}$ rozwojem miażdżycy tętnic, należy do nich głównie choroba niedokrwienna serca, która jest przyczyną wielu przedwczesnych zgonów, które wystąpiły przed 65 rokiem życia. Wśród czynników ryzyka choroby niedokrwiennej serca znajduje się 
czynnik związany ze stylem życia (dieta wysokokaloryczna obfitująca $\mathrm{w}$ tłuszcze nasycone i cholesterol, palenie tytoniu, nadmierne spożycie alkoholu, mała aktywność fizyczna) [1].

Takie czynniki ryzyka jak: palenie tytoniu, nadciśnienie tętnicze i wysokie stężenie cholesterolu odpowiadają za 25\% zgonów w tej grupie chorób. Palenie tytoniu powoduje zaburzenia gospodarki lipidowej: podwyższa stężenie triglicerydów i cholesterolu frakcji LDL, a obniża stężenie frakcji HDL, co nasila rozwój miażdżycy w naczyniach wieńcowych. Skurcze tych naczyń powodowane nikotyną oraz dodatkowo związanie części hemoglobiny przez tlenek węgla zmniejszają dowóz tlenu do mięśnia sercowego. Wypalenie 10 papierosów dziennie podwaja, a ponad 20 papierosów potraja zachorowalność na chorobę wieńcową. Mała aktywność fizyczna powoduje zaburzenia odporności ustroju na stresy i infekcje co sprzyja otyłości i przedwczesnemu starzeniu się oraz gorszej sprawności i intelektualnej. Jest czynnikiem ryzyka miażdżycy i choroby wieńcowej [2]. Ostre reakcje emocjonalne (lęk, złość) energicznie mobilizują katecholaminy, co powoduje zwiększone zapotrzebowanie mięśnia serca na tlen i może prowadzić do groźnych dla życia zaburzeń rytmu serca i do nadkrzepliwości. Reakcje stresowe mają znamienny wpływ na ukrwienie serca u osób z zaawansowaną miażdżycą tętnic wieńcowych [3]. W stylu życia duża rola przypada promocji zdrowia, dzięki której można kształtować zachowania, aby wpływały na poprawę stanu zdrowia, jednostki i całych grup społecznych [4].

Celem badań była ocena prowadzenia zdrowego stylu życia oraz kontroli stanu zdrowia przed i po zachorowaniu u pacjentów Oddziału Kardiologii i Pododdziału Intensywnej Opieki Kardiologicznej.

\section{Materiał i metody}

Badania przeprowadzono w Specjalistycznym Szpitalu Wojewódzkim w Ciechanowie. Grupę badaną stanowiło 70 pacjentów 
przebywających w Oddziale Kardiologii i Pododdziale Intensywnej Opieki Kardiologicznej.

Ankietowani pacjenci, którzy wzięli udział $\mathrm{w}$ badaniu to najczęściej osoby $\mathrm{w}$ przedziale wiekowym 51-60 lat. Osoby $\mathrm{w}$ tym wieku są częstszymi pacjentami oddziału kardiologicznego, niż osoby $\mathrm{z}$ innych grup wiekowych. W badanej populacji stanowili oni ponad połowę grupy (55\%). Opisując grupę badaną pod względem wykształcenia, można zauważyć zróżnicowanie w tym zakresie. $29 \%$ ankietowanych posiada wykształcenie średnie. Niewiele mniej bo $27 \%$ grupy to osoby posiadające wykształcenie zawodowe. Co czwarty uczestnik badania posiada wykształcenie podstawowe, a jedynie co piąty (20\%) wykształcenie wyższe.

Badania przeprowadzono metodą sondażu diagnostycznego. Jako narzędzie badawcze wykorzystano kwestionariusz ankiety własnej konstrukcji.

\section{Wyniki}

Przedstawione wyniki opracowano na podstawie badań własnych i dokonano analizy prowadzenia zdrowego i antyzdrowego stylu życia oraz jego kontrola przed i po zachorowaniu .

Postawiono pytanie ankietowanym na czym polega $\mathrm{w}$ ich odczuciu „zdrowy styl życia”, respondenci mogli wskazać kilka odpowiedzi, dlatego rozkład procentowy nie sumuje się do $100 \%$. Ponad połowa ankietowanych wskazała na odpowiednią dietę oraz aktywność ruchową jako elementy wskazujące na prowadzenie zdrowego stylu życia. Dla ponad $40 \%$ istotnym elementem zdrowego stylu życia okazały się też regularne posiłki $(42,86 \%)$, unikanie używek $(42,86 \%)$ oraz profilaktyka zdrowotna $(47,63 \%)$. W kategorii „inne” badani nie wskazali o jakich innych działaniach myślą. Te dane chociaż wydają się optymistyczne można zinterpretować w sposób przeciwny. Ponad połowa nie wybrała odpowiedzi „regularne posiłki, „uniknie używek” czy „stosowanie profilaktyki zdrowotnej” nie 
uwzględniając tych form aktywności jako elementy zdrowego stylu życia.

W kolejnym pytaniu pacjenci mieli określić jak interpretują pojęcie „antyzdrowego stylu życia”. Ponad połowa badanych wskazała, że ich zdaniem niezdrowy styl życia przejawia się przede wszystkim w braku systematycznej kontroli stanu zdrowia. Kolejne najczęściej wybierane odpowiedzi to „nieodpowiednie jedzenie”, "używki” oraz „brak ruchu”.

Łatwiej wskazać zmiany w sposobie życia analizując tabelę 1. Pokazuje ona, że przed zachorowaniem ok $57 \%$ badanych prowadziło zdrowy styl życia. Obecnie odsetek osób przyznających się do prawidłowych zachowań wzrósł aż do 87\%. Jednocześnie wyraźnie spadła liczba osób, które po zachorowaniu prowadza niezdrowy styl życia.

Tabela 1. Rozkład zmiennych pomiędzy prowadzeniem zdrowego stylu życia przed zachorowaniem a obecnie.

\begin{tabular}{|l|r|r|r|r|}
\hline Odpowiedź & \multicolumn{2}{|r|}{$\begin{array}{r}\text { Przed } \\
\text { zachorowaniem }\end{array}$} & \multicolumn{2}{|r|}{ Obecnie } \\
\cline { 2 - 5 } & $\mathrm{n}$ & $\%$ & $\mathrm{n}$ & $\%$ \\
\hline Prowadzenie zdrowego stylu życia & 35 & $57 \%$ & 54 & $87 \%$ \\
\hline Prowadzenie niezdrowego stylu życia & & & & \\
\hline Razem & 26 & $43 \%$ & 8 & $13 \%$ \\
\hline
\end{tabular}

Źródło: opracowanie własne

Znaczące zmiany zaszły wśród respondentów pod względem kontroli swojego stanu zdrowia. Warto dodać, że w tym przypadku zapytano pacjentów o systematyczne kontrolowanie stanu zdrowia, a nie jedynie okazjonalne wykonywanie badań w przypadku potrzeby 
hospitalizacji. Przed zachorowaniem co trzeci badany kontrolował swój stan zdrowia. Obecnie robią to prawie wszyscy pacjenci - 93\%. Wyraźnie spadał liczba osób, które obecnie, w porównaniu do czasu sprzed wystąpienia choroby nie kontrolowały swojego zdrowia. Obecnie jedynie 7 \% pacjentów tego nie robi.

Tabela 2. Kontrola stanu zdrowia przed i po wystąpieniu choroby.

\begin{tabular}{|l|r|r|r|r|}
\hline \multirow{2}{*}{ Odpowiedź } & \multicolumn{2}{|r|}{$\begin{array}{r}\text { Przed } \\
\text { zachorowaniem }\end{array}$} & \multicolumn{2}{|r|}{ Obecnie } \\
\cline { 2 - 6 } & $\mathrm{n}$ & $\%$ & $\mathrm{n}$ & $\%$ \\
\hline Kontrolowanie swojego stanu zdrowia & 18 & $30 \%$ & 55 & $93 \%$ \\
\hline $\begin{array}{l}\text { Niekontrolowanie swojego stanu } \\
\text { zdrowia }\end{array}$ & 42 & $70 \%$ & 4 & $7 \%$ \\
\hline Razem & 60 & $100 \%$ & 59 & $100 \%$ \\
\hline
\end{tabular}

Źródło: opracowanie własne

\section{Dyskusja}

Przeprowadzone badania na temat oceny przedchorobowego stylu życia pacjentów kardiologicznych i ich analiza wykazały, że częstszymi pacjentami oddziału kardiologicznego są osoby w przedziale wiekowym 51-60 lat (55\%).

Analizując wyniki badań niniejszej pracy można wywnioskować, że wykształcenie, miejsce zamieszkania, sytuacja materialna pacjenta mają wpływ na przedchorobowy styl życia. Można porównać to założenie z wynikami Andrzeja Wojtczaka, który ukazuje zależność pomiędzy poziomem wykształcenia,a zachowaniami jednostki oraz pozycją zdrowia $w$ jej hierarchii wartości. Wykształcenie jest najbardziej znaczącym czynnikiem kształtującym zachowania zdrowotne ludzi. Posiadana wiedza zwiększa świadomość istoty przestrzegania i wpływa to bezpośrednio na stan zdrowia. Również czynniki społeczno-ekonomiczne wpływają na liczbę 
zachorowań. Zła sytuacja materialna i niski poziom wykształcenia są największym zagrożeniem [2].

Z wyników przeprowadzonych badań niniejszej pracy wynika, że pacjenci po wystąpieniu choroby zmieniają styl życia na bardziej prozdrowotny. Przed zachorowaniem (57\%) pacjenci prowadzili zdrowy styl życia, a do prawidłowych zachowań wzrósł on do 87\%.

Temat zmiany stylu życia również porusza Violetta Korporowicz w książce „Promocja zdrowia kształtowanie przyszłości”. Osoby zmieniają swą postawę wobec swojego stanu zdrowia często w wyniku negatywnego doświadczenia zdrowotnego. Dopiero wtedy stosują posiadaną wiedzę prozdrowotną. W skrajnych przypadkach dokonują analizy stylu życia i rezygnują z preferowanych wcześniej zachowań. Obniżona sprawność organizmu zmusza do poszukiwania odpowiedniego stylu życia, które może pomóc zmniejszyć lub wyeliminować zagrożenia obniżające stan zdrowia [5].

$\mathrm{Z}$ analizy wyników badań także można stwierdzić, że pacjenci kardiologiczni nie znają negatywnych skutków antyzdrowotnego stylu życia. 63\% ankietowanych odpowiedziało, że nie są ich świadomi. Co trzeci badany stwierdził, że są mu znane.

Włodzimierz Piątkorski opisuje, że ludzie często nie dbają o swoje zdrowie, świadczy o tym nie tylko brak zachowań prozdrowotnych, ale także to, że świadomie postępujemy w sposób szkodliwy dla zdrowia, a przy tym nie robimy nic lub nie wiele, aby zmienić taki stan rzeczy. Ponad $42 \%$ to zachowania generalnie niekorzystnie wpływające na zdrowie, a kolejne $6 \%$ nie potrafi dokonać oceny ich wpływu. $62 \%$ osób swoje antyzdrowotne zachowania uzasadniały przede wszystkim przyzwyczajeniem, 56\% przyjemnością z nich płynącą, niechęcią do ograniczania się (54\%), brakiem refleksji nad zdrowotnymi skutkami własnych działań (52\%), wynikającymi z nich poczuciem odprężenia (52\%), czy przekonaniem, że zdrowiu bardzo szkodzą inne rzeczy niż takie zachowania (47\%). Czynniki w dużej mierze zależne od jednostek, a więc wyjaśniane nimi zachowania są przedmiotem względnie nieskrępowanego wyboru [6]. 


\section{Wnioski}

Przeprowadzona analiza materiału badawczego pozwala porównać prowadzenie zdrowego stylu życia oraz kontrola stanu zdrowia przed i po wystąpieniu choroby u pacjentów kardiologicznych.

Rozważania teoretyczne oparte na dostępnej literaturze przedmiotu oraz uzyskane wyniki $\mathrm{w}$ procesie badawczym wraz $\mathrm{z}$ analizą doprowadziły do wniosków:

- $\quad$ Kontrola stanu zdrowia u pacjentów kardiologicznych uległa poprawie po wystąpieniu choroby.

- Zebrany materiał badawczy stanowi podstawę do potwierdzenia hipotezy, że pacjenci po wystąpieniu choroby zmieniają styl życia na bardziej prozdrowotny

\section{Zalecenia dla praktyki pielęgniarskiej}

Przedstawiona praca miała na celu wskazanie problemu nie przestrzegania zdrowego stylu życia przed i po rozpoznaniu choroby kardiologicznej. Należy zwrócić uwagę na konieczność zastosowania profilaktyki. Istotą sprawy jest także ukazanie konieczności prowadzenia przez pielęgniarki edukacji zdrowotnej pacjentów, którą powinno się prowadzić zarówno przed jak i po zachorowaniu. W konsekwencji mogłaby ona zapobiec wystąpienia możliwych powikłań choroby kardiologicznej.

\section{Bibliografia / Bibliography:}

1. Kulik T.B., Latalski M.: Zdrowie publiczne Wydawnictwo Czelej Lublin 2002, 94-104.

2. Wojtczak A.: Zdrowie publiczne. Wydawnictwo Lekarskie PZWL Warszawa 2009, 115,124-125,77.

3. 
4. Kuński H.: Promowanie zdrowia Podręcznik dla studentów wychowania fizycznego i zdrowotnego Wydanie II uzupełnione Wydawnictwo Uniwersytetu Łódzkiego Łódź 2000, 159.

5. Siciński A., Styl życia- problemy pojęciowe i teoretyczne, Warszawa, PWN 1976, 15.

6. Korporowicz V.: Promocja zdrowia kształtowanie przyszłości Szkoła Główna Handlowa w Warszawie- oficyna wydawnicza Warszawa 2008, 123.

7. Jabłońska T.E.: Profilaktyka uzależnień tytoń, alkoholizm, narkomania Pielęgniarka i Położna 2004, 11-12. 